\title{
TURNOUT DECLINE IN ROMANIAN NATIONAL ELECTIONS: IS IT THAT BIG?
}

\author{
MIRCEA COMȘA ${ }^{1}$
}

\begin{abstract}
According to official data, Romanian voter turnout decreased by half for the period 1990-2012. Gaps between official and self-reported turnout are larger than those from similar countries. Starting with these findings, this paper questions the official data regarding turnout and brings evidence that turnout in Romanian elections is increasingly underestimated. Three factors are responsible for this: the quality of the electoral registers, ineligible voters and emigration. The effect of these factors grew over time inducing the idea that turnout is sharply decreasing. In fact, the decrease is less pronounced, and most of it took place between 1990 and 2000. In the last part, I discuss the implications of the findings in three domains: theoretical debates, methodological and practical issues.
\end{abstract}

Keywords: turnout decline, official turnout, voting age population, voting eligible population, apparently voting eligible population

\section{Introduction: two questions about voter turnout in Romania ${ }^{2}$}

Voter turnout (VT), regardless of the type of election and country, has decreased in the last 50 years (Franklin et al., 2000; Heath, 2007; Wattenberg, 2002). The average turnout rate for 22 countries for the period 1945-1999 decreased from $83 \%$ to $77 \%$, with the decrease being more significant after 1965 (Franklin et al., 2000). The decrease in turnout appears to characterize the majority of the democracies. The turnout rate in Britain has decreased over the last 50 years (1950-2005) by $20 \%$, from around $80 \%$ to around $60 \%$ (Heath, 2007). The turnout rate in the United States (US) increased until 1958, then it decreased (Teixeira, 1992; Wattenberg, 2002). Canada has registered a seven-point drop in turnout rate (Blais et al., 2004). Turnout rate decreased in Denmark, Germany, the Netherlands, Norway and Sweden too (Gallego, 2009).

\footnotetext{
${ }^{1}$ Sociology Department, Babeș-Bolyai University Cluj-Napoca, e-mail: mcomsa@socasis.ubbcluj.ro.

2 I wish to thank to Cristina Stănuș, Bogdan Voicu, and Camil Postelnicu for their helpful comments and suggestions on previous versions of this paper. This work was financially supported by CNCSIS-UEFISCSU grants PN-II-ID-PCE-2011-3-0669 and PN-II-ID-PCE-2011-3-0210.
} 
Also, voter turnout dropped sharply in post-authoritarian Latin America and post-communist Europe after the founding elections (Bernhagen and Marsh, 2007; Kostadinova, 2003; Kostadinova and Power, 2007).

The official turnout rate in Romania follows the same tendency. As shown in Figure 1, according to official data (Central Electoral Bureau - BEC), the decrease in turnout is quite large. Even if one ignores the founding elections and the last two parliamentary elections (these took place detached from the presidential elections and are arguably different compared to previous elections), one observes that the official turnout rate in the national elections has decreased by approximately $20 \%$ (from 76.3\% in the general elections of 1992 to $54.4 \%$ in the presidential elections of 2009).

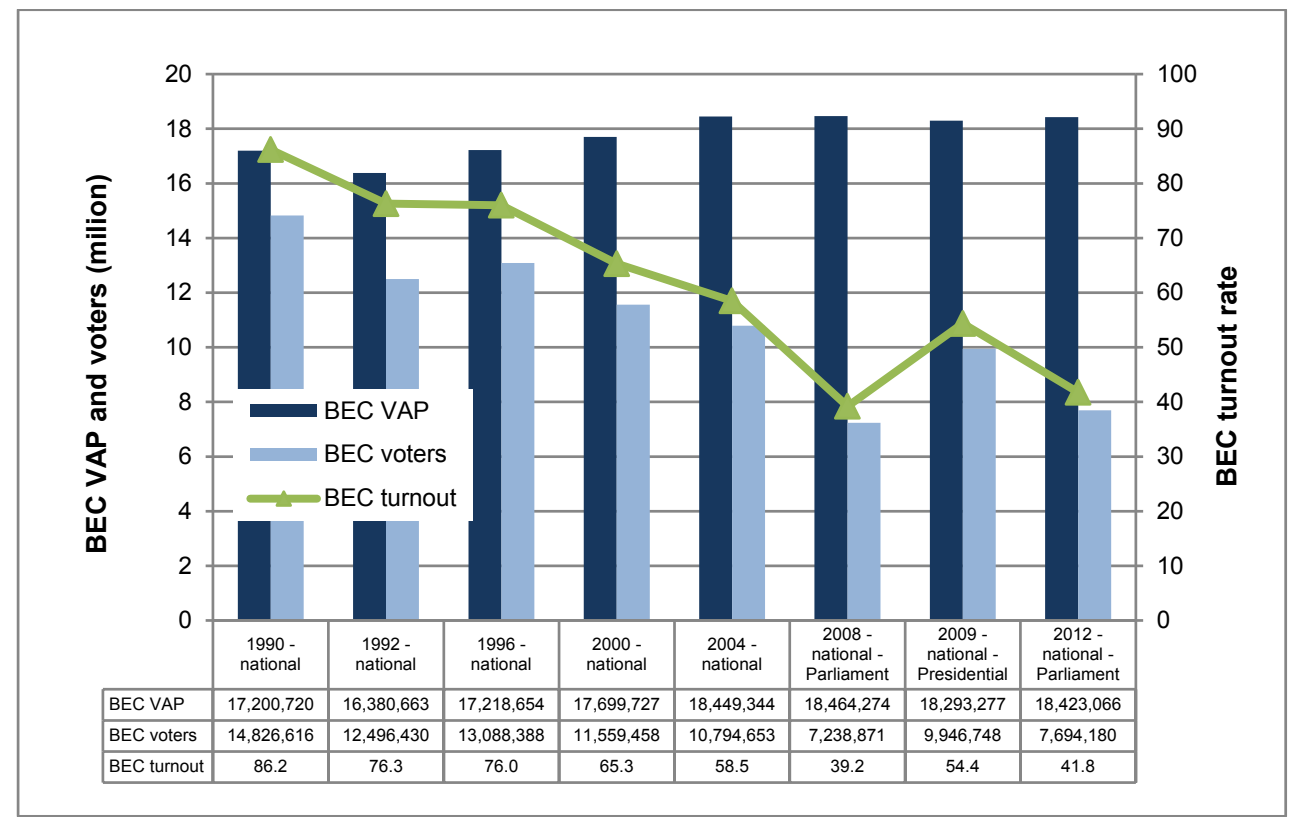

Figure 1. Official (BEC) turnout rate in Romania, 1990-2012

Data sources: BEC (www.bec2004.ro, http://www.becparlamentare2008.ro, www.bec2009p.ro, http://www.becparlamentare2012.ro), ROAEP (http://www.roaep.ro),

INS (Tempo Online, www.insse.ro) ${ }^{3}$

The literature proposes a set of hypotheses about the factors behind turnout decline in former Communist countries, Romania included. Rose (1995) states that turnout decline is the consequence of post-communist demobilization:

3 For the 1990 election no official data is available regarding the size of the electorate and turnout. Presented data are from Bejan (1991: 112). 
because the citizens are now free, they choose to not participate. A weak civil society and a low level of social capital (Howard, 2003; Norris, 2002) are other possible factors that could lower the turnout. The 'post-honeymoon effect' hypothesis (Inglehart and Catterberg, 2002; Kostadinova, 2003) states that right after the fall of communism the citizens are enthusiastic and have high expectations but, shortly after that, they feel deceived and, consequently, absenteeism grows. Following this line of thought, literature identifies two other hypotheses: deteriorating economic conditions and deteriorating political conditions. The first years of new democracies are characterized by severe and growing economic hardships (hyperinflation and high unemployment rates), which have a negative impact on VT (Bell, 2001; Mason, 2003; Pacek, 1994; Tworzecki, 2003). Also, after an initial phase of relative stability, the political conditions change for the worse (extreme inter- and intra-party instability, political scandals, corruption, illegal practices within parties) (Hutcheson, 2004; Kostadinova, 2003; Kostadinova, 2009; Stockemer et al., 2013; Sundström and Stockemer, 2013; White and McAllister, 2004), and this contributes to turnout decline. The 'electoral stakes' hypothesis (Pacek et al., 2009) states that after the fall of Communist parties, people start to learn to identify the elections that are more important and, consequently, worth their time and effort. Are these explanations complete, or there are some other important factors behind the turnout figures?

Survey-reported turnout is always higher compared to official turnout (Bernstein et al., 2001; Clarke et al., 2004; Comșa, 2010; Denver, 2003; Duff et al., 2007; Mattila, 2003; Rotariu and Comşa, 2005). This is true no matter which population is under study or which data collection technique is used (face-to-face or telephone surveys). From this point of view, Romania is no exception. Some recent examples are relevant towards this point. In a survey carried out immediately after the 2000 general elections in Romania, 84\% of the respondents stated that they had voted, when the official turnout was only 65\% (Comşa, 2004). The official turnout (Central Electoral Bureau - BEC) at the general elections (parliamentary and presidential) of 2004 was $58.5 \%$ for the first round, and $55.2 \%$ for the second. Six months later, for the same election, the self-reported turnout was $83 \%$ for the first round, and $77 \%$ for the second (BOP, May 2005). Approximately six months after the parliamentary elections of 2008, 69\% of the respondents of the Romanian Electoral Studies (SER) survey stated that they had voted, with the official turnout reported as just 39.2\%. The official turnout (http://www.bec2009pe.ro/statistici.html) for the European Parliament of 2009 was $27.7 \%$, but $49 \%$ of the respondents of the SER survey carried out immediately after the elections stated that they had voted. In the case of the presidential elections in the same year the difference 
is even bigger, reaching almost $30 \%$ for both rounds. According to the BEC (http://www.bec2009p.ro/statistici.html), the official turnout was $54.4 \%$ in the first round and $58 \%$ in the second $53.9 \%$ and $57.2 \%$ if voters from diaspora are excluded). The self-declared turnout was $82 \%$ for the first round and $85 \%$ for the second round (SER 2009).

Turnout overestimation by $20-30 \%$ is high in itself. Additionally, compared to the average situations of other countries, overestimation appears to be significantly higher in Romania (at least for the elections taking place after 2000). Regardless of whether I compare Romania to other European countries or just the former Communist ones, or look at the parliamentary elections or the European ones, the conclusion is the same (Figure 1). Thus, utilizing the CSES II and IDEA data (both official and voting age population - VAP), I have calculated that the average overestimation of VT in the last national elections of the European states (19 countries) ${ }^{4}$ is $6.9 / 8.9 \%$ (the first value represents the average of the overestimation using the official turnout, and the second the average using the VAP turnout according to the IDEA turnout data), $11.8 / 14.1 \%$ if I consider only the former Communist states and $18.7 / 17.4 \%$ in the case of Romania. Utilizing data from ESS round 3 (24 countries) and the IDEA turnout rate (both official and VAP for the latest national elections) I reach somewhat higher values of overestimation: $9.4 / 13.6 \%$ at the European level, $12.4 / 16.9 \%$ in the former Communist countries and $24.5 / 19.8 \%$ for Romania. Following the same procedure, but using ESS round 4 (3rd version, 26 countries) data, I obtain values rather similar to the ones from round 3: $11.9 / 13.3 \%$ at the European level, $16.0 / 17.3 \%$ for the former Communist countries and $28.6 / 26.3 \%{ }^{5}$ (parliamentary elections) or $28.5 / 25.1 \%$ (presidential elections) for Romania. In the 2004 elections for the European Parliament (22 countries), I obtained overestimations of $16.7 / 18.2 \%$ at the European level, $13.7 / 14.6 \%$ in the former Communist countries and $21.3 / 20.2 \%$ for Romania. The inherent question that arises from these findings is: Why is the difference between official and selfreported turnout so high in Romania?

Even though these two questions seem to be unrelated, I will show that they have a common answer: there are problems related to turnout computation, and more specifically, the estimation of the total number of voters (turnout rate denominator or the size of the electorate). In the Romanian post-communist context, the number of voters that can really vote is difficult to estimate for three reasons: the problems associated with maintaining accurate electoral lists, ineligible voters and a large (temporary) migratory population. Taking these

\footnotetext{
${ }^{4}$ All these data are available from author, upon request.

5 Regarding the same elections, but at a distance of 6 months, the over-estimation observed in the SER study was 29.7/27.5. ESS data for Romania were collected by CSOP after approximately two months from the Parliamentary elections.
} 
factors into account, I show that the turnout rate in the Romanian national elections is increasingly underestimated. The effects of these factors are growing over time, falsely inducing the idea that turnout is sharply decreasing (as in all the states analyzed in the literature), when in reality this decrease is less pronounced and most of it is concentrated between 1990 and 2000. Our findings about the Romanian turnout are supported by validation analyses: the link is not a spurious one; the re-estimated turnout pattern is closer to the average turnout pattern from Communist countries, and the same findings apply to Moldavia and possibly to other former Communist countries. ${ }^{6}$ Finally, I present conclusions and discuss the implications of the findings about turnout decline for three areas: theoretical debates, and methodological and practical issues.

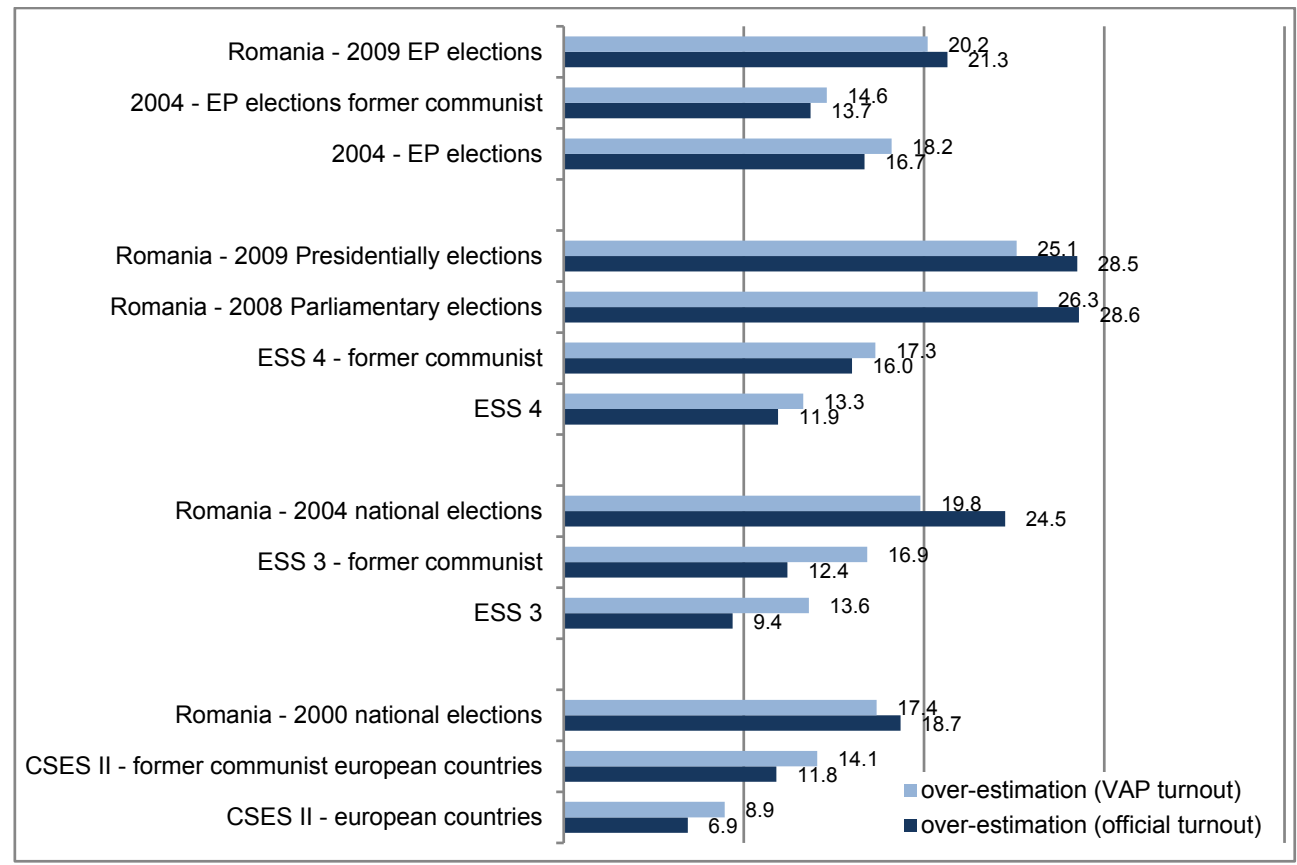

Figure 2. Turnout overestimation in comparative perspective: differences between survey data and official turnout

Source: Personal computations based on CSES, ESS, and SER surveys.

\footnotetext{
${ }^{6}$ In a working paper that takes into account 30 former communist countries and 272 elections I show that turnout decline is strongly negativelly correlated with emigration size even after controlling for most relevant determinants of turnout.
} 


\section{Turnout overestimation and electorate size}

Systematic turnout overestimation can be the result of several factors (Holbrook and Krosnick, 2010): survey-related measurement errors (methods: social desirability, memory errors, and acquiescence; sampling: selection bias and panel conditioning) and official data-related measurement errors (incorrect denominator and/or an incorrect enumerator). The errors specific to the survey methodology have been discussed extensively in the scholarly literature. However, relatively little attention has been given to errors that might occur in terms of official data. The official turnout is computed by dividing the number of voters (enumerator) by the number of the electorate (denominator).

The number of voters is, broadly speaking, usually estimated without major errors. In the case of new democracies and for the founding elections in particular, this statement is debatable. The reason is linked to the occurrence of electoral fraud of the following types: multiple voting or voting for another person. The possibility of these situations occurring is mentioned, among others, by Carey (1995), regarding the general elections of 1992 in Romania. According to the author, the proportion of fraud is difficult to estimate, but it can reach approximately $10 \%$ of the total votes cast (in the case of the aforementioned elections, the proportion of the votes cast on special lists was $13 \%$ of the total votes, that is to say, 1.57 million). Very likely, the proportion of such situations decreases over time. This fact is backed up by the decrease in the number of votes cast on special lists, and the decrease in the percentage of these votes out of the total votes cast $(0.2$ million in the case of the parliamentary elections of 2008 and 0.8 million in the presidential elections of 2009 , that is to say $3 \%$ and $8 \%$ ). The proven situations of fraud due to multiple votes are much less, but I do have at disposal data for the general elections of 2004 and the elections for the European Parliament in 2009. Thus, the percentage of multiple voting situations in the general elections of 2004 in Ilfov County (only 9,322 votes from several localities have been analyzed, most probably from rural areas; of these, 351 were cases of multiple voting) was 3.8\% of the total votes cast (APD 2005: 477). Regarding the elections for the European Parliament in 2009, the Permanent Electoral Authority (AEP) ${ }^{8}$ recorded only 12,034 possible cases of multiple voting at the national level, that is to say $0.25 \%$ of the total votes cast. The situations of multiple voting and voting in another person's place lead to an artificial increase in the official turnout. Additionally, if the weight of such a situation has decreased significantly over time, the decrease of the turnout in Romania is not as steep as the official data show. Estimating the real percentages of the situations that artificially increase the number of votes cast is difficult, if not impossible, for all elections; therefore I choose not to discuss it here.

\footnotetext{
7 http://www.apd.ro/publicatie.php?id=2

8 Press release from 15.01.2010, http://www.roaep.ro/ro/section.php?id=9
} 
The same thing cannot be said of the size of the electorate. I think that, at least in the case of certain countries, Romania included, relatively large errors can occur in estimating the size of the electorate, with consequences for turnout computation. This idea is not new. In the context of the discussions concerning the decrease in the turnout rate in the US over time, a series of analyses have contested the validity of such observations, stating that the decrease in participation is just an illusion (McDonald, 2003; McDonald and Popkin, 2001). Same authors show that a decrease in turnout can only be seen if VAP is used as a denominator. This happens because VAP includes different categories of individuals that are ineligible to vote (felons, non-citizens, mentally incapable). ${ }^{9}$ Given that the number of ineligible voters has increased over time, it appears that turnout has decreased. By excluding people that are ineligible to vote from the VAP, one obtains the voting eligible population (VEP). According to these scholars, if VEP is used as a basis for reporting turnout, the conclusion is completely different - turnout is relatively constant after 1972 . Another analysis (Burden, 2003) shows that even using VEP, the turnout still decreases, although the decrease is not as large as when using VAP as a basis for reporting. Based on these findings, one can conclude that the turnout measures constructed using VAP estimates understate turnout size and overstate turnout decline in the US.

In the following, I show and discuss similar problems that are affecting the estimation of VAP in Romania. I argue that turnout decline has two sources: the decrease in the number of voters (from 12.5 million in 1992 to almost 10 million in 2009 and 7.7 in 2012) and the increase in the size of the electorate (BEC VAP). In the 1990-2004 period the electorate size increased from 16.4 to 18.5 million, only to oscillate afterwards around the 18.3 million mark (Figure 1). This finding is startling if one takes into account the fact that the population of Romania (total, but also the adult population) has decreased during this period, according to the National Institute of Statistics (INS) data (TEMPO-Online, www.insse.ro) and other analyses (Rotariu, 2010). This has happened because the computation method of the total number of voters in Romania has three major faults: the quality of the electoral registers, ineligible voters and emigration (permanent, but unofficial, and temporary or cyclical) (Comșa, 2004; Comșa, 2010).

\section{The number of voters and the quality of the electoral registers}

According to the Romanian Constitution (Article 36), in order to vote, a person has to be an adult Romanian citizen, who has not had this right revoked. In 2009, according to the INS data, the number of adults in Romania was approximately 17.5 million. In the same year, the official BEC documents

\footnotetext{
${ }^{9}$ The percentage of those excluded (overseas) is significantly lower (McDonald and Popkin, 2001).
} 
put the total number of eligible voters in Romania (based on existing electoral lists) at 18,197,316 in the European Parliament elections and 18,293,277 for the presidential elections. ${ }^{10}$ Given that the two elections were separated by only 6 months, the increase in the adult population by 100,000 is rather surprising and highly improbable. However, even more surprising is the difference (0.7-0.8 million) between the number of eligible voters estimated by the two sources (BEC and INS). This difference is not specific to the year 2009, it can be found in the other electoral years too (with the exception of 1992, where the two estimates are similar), as Figure 3 shows.

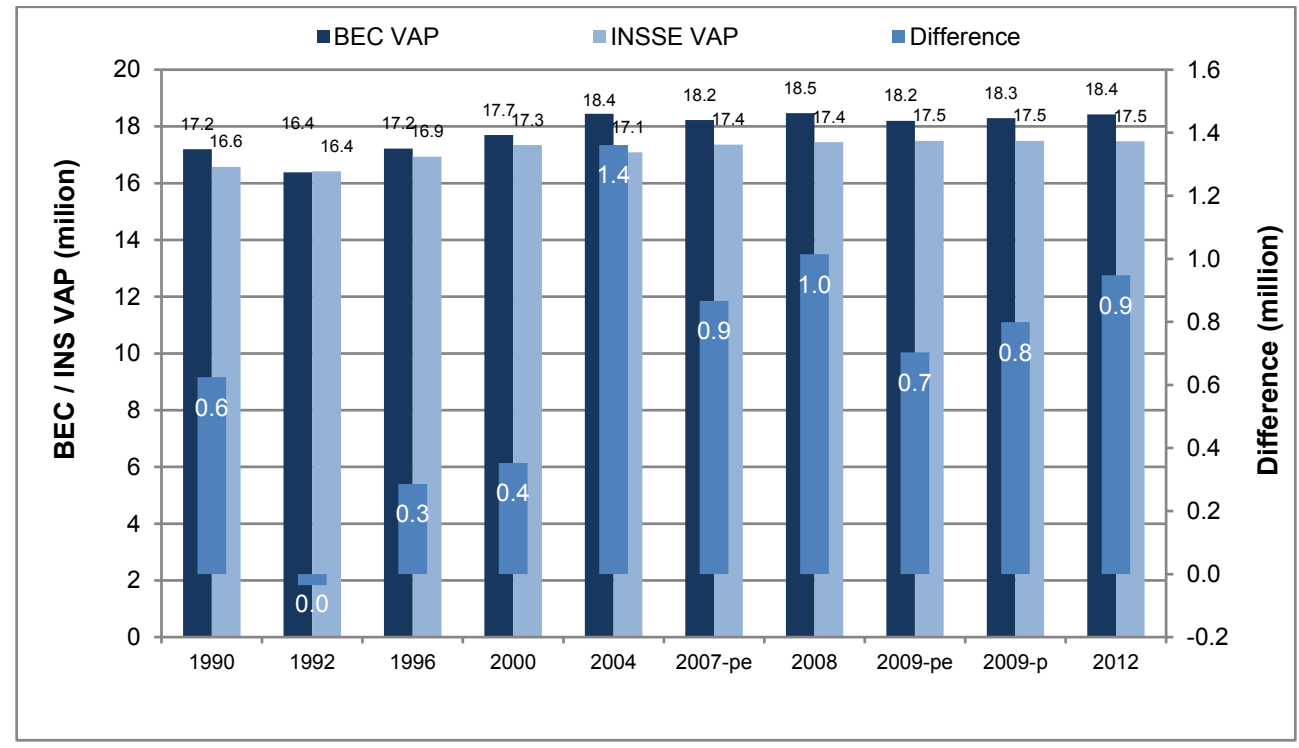

Figure 3. Voting age population according to BEC and INS, Romania 1990-2012

Data source: BEC (www.bec2004.ro, http://www.becparlamentare2008.ro, www.bec2009p.ro, http://www.becparlamentare2012.ro), ROAEP (http://www.roaep.ro), and

INS (Tempo Online, www.insse.ro)

The difference between the BEC and INS data originates from the method of constructing, keeping and updating the electoral registers in Romania. According to the law 370/2004 (article 12, paragraph 2), the electoral lists are based upon the lists provided by the National Centre for the Administration of the Databases Regarding Population Records. Due to some errors, these lists (and implicitly, the electoral lists) contain more adults than are present in Romania. Of course, there

${ }^{10}$ Sources: http://www.bec2009pe.ro; http://www.bec2009p.ro. 
are also situations in which people are not present on the lists. At elections, this type of voter is counted on supplementary electoral lists. For example, in the elections of 2009 for the European Parliament, 668,217 persons voted on such lists. There are two major sources of errors in BEC's electoral registers: double inclusion (people that have moved are sometimes counted twice, at both the old and the new address) and un-exclusion (some deceased people are still included in the electoral registers). ${ }^{11}$ This situation can be best observed by analyzing survey research responses with samples based on the electoral lists. After analyzing the contact forms from surveys carried out between 2000 and 2009,12 on similar samples, it was found that, on average, from the total number of people selected from the electoral lists, $13.6 \%$ were incorrect entries $(1.4 \%$ non-existent/uninhabited residences, $2.1 \%$ deceased, $10.1 \%$ no longer lived at the respective address). ${ }^{13}$ Even if one assumes that these figures are much smaller in reality, it still adds up to the fact that approximately ${ }^{14} 1.2$ million people out of the 17.8 million total should not be included in the electoral lists. Consequently, the real number of eligible voters is around the 16.8 million mark, a value closer to the INS estimation (17.1 million, average for the entire period). The aggregate effect of this situation leads to 'supplementing' the number of adults in Romania by a figure comprised within the 0.3-1.4 million range (with the exception of the 1992 elections). Even more startling, according to the electoral registers, the adult population in Romania has increased by almost 150,000 in a very short period of time (June-October 2009), a very unlikely situation if one considers the negative natural growth rate of the population of Romania according to the INS data (www.insse.ro). Relative to all of the elections, on average, the size of the electorate according to the BEC is higher by almost 0.7 million compared to the size calculated by the INS. Another point of interest for our analysis, this 'supplementing' was not constant; it tended to increase over time with the highest value reached for the 2004 elections (on average, 0.3 million before 2004,

${ }^{11}$ Estimations referring to Great Britain point out that between 6 and $9 \%$ of the number of entries are redundant or duplicate (Swaddle and Heath, 1989). On the other hand, persons that have moved are also under-represented in surveys, leading to an over-estimation of the turnout due to sampling.

12 The surveys included are: Political Barometer (MMT, October 2000 and October 2002), Public Opinion Barometer (May 2001, May 2003, May 2006, May 2007), Interethnic Relations Barometer (2002), European Values Survey (2008), The attitudes of Romanians towards work (May 2008), Romanian Electoral Studies (June 2009 and November 2009).

13 The quality of the electoral lists varies not only in time (the percentage of double inclusions and unexclusions has decreased from $15.7 \%$ for the period of $2000-2004$ to $11.5 \%$ for the period of 2005 2009) but also during an electoral cycle. In regards to the latter part of the statement, the percentage of the reasons pertaining to the sampling framework of the totality of the reasons why the questionnaire was not applied to a certain address has increased for the period of 2000-2002 from $32 \%$ to $47 \%$ (Comşa, 2002).

${ }^{14}$ Average values referring to national elections from 1990 to 2012. 
0.8 million after 2004). In these conditions, even if the electorate participated in the elections to the same degree, the turnout would still have decreased due to the false increase in the voting age population.

\section{Apparently voting eligible population (AVEP)}

Not all adult citizens of Romania have the right to vote. According to the Constitution (Article 36, paragraph 2), 'the mentally debilitated or alienated, placed under interdiction, do not have the right to vote, nor do the persons convicted, by an irrevocable judicial sentence, to the forfeiture of the electoral rights'. Even if the suspension of the right to vote in the case of the irrevocably convicted is sometimes up for discussion, ${ }^{15}$ the general situation is usually that convicted and incarcerated people either do not have the right to vote or they do not vote. Data provided by the Ministry of Justice to the INS (Figure 4; Table 3 in the Appendix) indicate that approximately 22,000 to 36,000 potential voters most likely did not have the right to vote. Although the number of these individuals varies greatly, it does not follow an increasing or decreasing tendency. Important for our endeavor is the fact that the percentage of people in this category is relatively small compared to the total $\operatorname{VAP}(0.2 \%$ at most). The same thing cannot be said for the percentage of adults with psychological or mental disability. According to the data provided by the National Authority for Persons with Disabilities (ANPH), the percentage of these adults in the VAP increased from $0.1 \%$ in 1990 to approximately $1 \%$ in 2012 (Figure 4; Table 3 in the Appendix). The majority (95\%) of these individuals fall into the first two categories of disability (severe and accentuated). Consequently, I can classify them in the categories of people who most likely do not have the right to vote or who can find difficult to cast a vote.

All of the previous studies (Czesnik, 2006; Kostadinova, 2003; Kostadinova and Power, 2007; Kostelka, 2010; Pacek et al., 2009; Rose, 1995) have ignored a major phenomenon that affects most Eastern European countries, namely, migration, as a potential explanatory variable of turnout decline. Migration can lower turnout by increasing the cost of voting due to higher distances to the polling stations. Moreover, if migration flows are increasing over time, the turnout decline will be

\footnotetext{
15 According to Article 3 of the additional Protocol of the European Court of Human Rights, limiting the right to vote in the case of the convicted is an infringement of human rights. For example, by the Sentence of the ECHR of July $1^{\text {st }} 2008$ given in the case of 'Calmanovici versus Romania', the ECHR condemned Romania for the first time for the interdiction of parental rights and electoral rights as an accessory punishment to a criminal conviction, towards the plaintiff Viorel Calmanovici. He claimed the infringement of several rights provided by the Convention, among others the right to vote during incarceration within the country.
} 
more pronounced. For Romania, temporary migration ${ }^{16}$ represents the biggest source of VAP reduction. From certain points of view, the exclusion of this category from VAP is debatable. Even if, according to electoral law, the temporary migrants do not lose their voting rights, their exclusion from the voter pool is justifiable if one takes into account the high cost of voting in their case. The largest number (294) of polling stations abroad was recorded during the 2009 presidential elections. Even though a large share of these are located in countries with a high percentage of Romanian emigrants (Italy 55, Spain 38, US 28), the number of stations is still insignificant relative to the size of the countries that they cover. Therefore, the time and money needed to reach a polling station are significant. Consequently, the emigrant turnout rate is quite small: around 1\% for the 2009 European Parliament elections, 5\% for the 2009 presidential elections (first round), and 3\% for the 2012 parliamentary elections (the number of votes from abroad was computed using data provided by the BEC; the method for estimating the total emigrant population is described below).

In one of the first studies on the subject (Sandu, 2000), the rate of cyclic migration during the year 2000 was estimated at $19 \%$ of the adult population, or approximately 0.4 million. In subsequent studies (Comşa, 2002, 2004), the number of Romanian emigrants in 2002 was estimated at nearly one million. Meanwhile, most sources indicate that the number of emigrants (for longer periods of time) has at least doubled by 2006 (**, 2006; Sandu, 2006), with an upward tendency after 2006 (as a consequence of Romania's accession to the EU). A more recent source (Sandu, 2010) estimates the total number of temporary Romanian emigrants at 2.2 million in 2006, 2.7 in 2007 and 2.8 in 2008.

An estimation of the number of Romanian emigrants for the period 1990-2012 is difficult to carry out. Official data are missing, incomplete, or are affected by errors. Some examples are relevant towards this point: the INS

${ }^{16}$ Here we talk only about external migration. In some cases, being an internal (temporary or not) migrant reduces also the turnout probability. The extent of this phenomenon is difficult to estimate, but it is present, especially in the case of 2009 elections. The number of persons that voted on supplementary lists at the last two presidential elections (2004 and 2009) supports this statement: 705,739 persons voted on supplementary lists in 2004 and 479,613 in 2009. The difference between the two figures is at least partially a direct result of the electoral law change. According to the new electoral law (The Government Emergency Ordinance no. 95, Official Gazette of Romania, no. 608 / 2009 , September 3), a citizen can only vote in the voting station to which his respective address is allocated, with two situations possible: he or she is included in the permanent electoral lists or he or she is not included in those lists but can prove with an identification document his or hers residence in the area covered by the respective voting stations. If neither applies, then voting is possible only in special voting stations. For previous elections all voters unable to vote in the voting stations corresponding to their domiciles could vote in other voting stations, where they were included on special lists. The introduction of special voting stations for these persons, usually limited to one per local government, raised the costs of voting for the more mobile citizens, the consequence being lower turnout of this category (Rotariu, 2010). 
measures only permanent emigration, ignoring temporary emigration; the volume of remittances estimated by the National Bank of Romania (BNR) is based only on the institutional channels of money transfers; and most often, the EU countries' statistics only present the number of emigrants for recent years. In order to avoid errors associated with only one source and method of estimation, but still cover the whole period of interest, I decided to use three methods of calculating the number of adult emigrants: an estimation based on the volume of remittances, estimations from the official statistics of countries that have attracted the largest part of the Romanian emigrants, and estimations based on the analysis of electoral registers. The resulting data are presented in Table 2 in the Appendix. I briefly present the estimation methods below.

Starting with the method of estimating the number of emigrants on the basis of remittances put forward by Sandu (2010), I propose a partially modified version. Given that the volume of remittances estimated by the BNR includes only formal channels, I have weighted the values to cover for informal channels as well, thus estimating the 'real' volume of the remittances. Then I estimated the average volume of remittances transmitted by an emigrant in a year, starting with the average value of these for the year 2008: 4700 euro according to the survey data (Sandu, 2010). Then I weighted the data with the real GDP growth rate at the level of the EU (according to the IMF data) in order to obtain the estimations for the entire period of interest. By dividing the "real" volume of remittances by the average volume sent by an adult emigrant, I obtained the number of adult emigrants that have sent remittances. Because not all adult emigrants send remittances, I have weighted the values with the percentage of those that most likely do, thus resulting the estimated number of adult emigrants. According to recent survey data (Sandu, 2010), of the total number of emigrants, approximately $60 \%$ send money to their relatives in their country of origin. I estimate that this percentage has decreased over time, therefore the percentage was higher in the previous years (I have approximated a decrease of one percentage point per year).

At least in recent years, the majority of Romanian emigrants, approximately 66\% for the year 2006 according to the survey data (Sandu, 2010), live in Italy and Spain. Based on the official statistics provided by the statistical offices of these countries, 17 and considering that the percentage of migrants in these countries was on the rise during the period of 1990-2012 from 30\% to $72 \%$, I have obtained the total number of emigrants. Of these, only some are adults

\footnotetext{
17 Italy: 1990-2002 (MPI, http://migrationinformation.org/GlobalData/countrydata/data.cfm), 2003-2009 (ISTAT, http://demo.istat.it), Spain: (INE, http://www.ine.es/en/daco/daco42/migracion/evr2008_en.xls).
} 
(approximately $90 \%$ up to $2000,80 \%^{18}$ after). Given that most likely the official statistics underestimate the number of Romanian emigrants, I have corrected the estimations, taking into account the declining rate of underestimation from $70 \%$ in 1990 to $29 \%$ in 2012 (Table 2 in the Appendix).

An analysis of the reasons why some of the individuals selected from the electoral lists to take part in a survey were unreachable shows that $7-8 \%$ of them were working abroad (based on surveys: SER, June and November 2009, and 'The attitudes of Romanians towards work', May 2008). If one considers the situations that are not reported to the interviewers (entire families migrating or single people migrating), the percentage of emigrants is probably much higher, maybe almost double. Therefore, approximately $10-12 \%$ of the electorate, that is to say 1.8-2.2 million, is not in the country most of the time.

In the end, for each year, I have calculated the average of the obtained estimations. For most years, only one or two estimations were available. For the founding elections, the number of emigrants is relatively negligible, but starting with 2004 one can observe an exponential increase that leads us to more than two million adult emigrants in later years (Figure 4). In the same figure, I present what I call the "apparently voting eligible population" (the sum of the voting ineligible population and the migrant population).

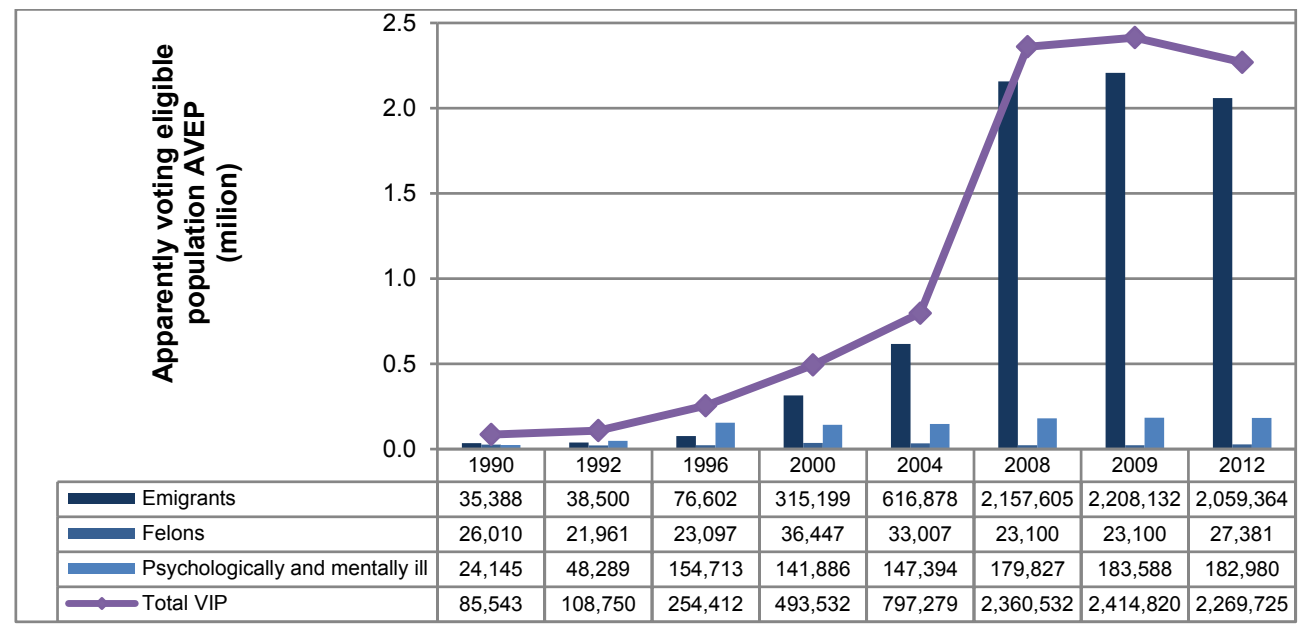

Figure 4. Apparently voting eligible population (AVEP), Romania 1990-2012

Data source: The number of psychologically and mentally ill adults - ANPH (http://www.anph.ro/tematica.php?idt=13\&idss=41); the number of adults' irrevocably convicted - INS (TEMPO-Online, www.insse.ro); number of adults temporally emigrated - personal estimations (Appendix, Table 2).

\footnotetext{
${ }^{18}$ According to data from surveys carried out in recent years (Sandu, 2010).
} 


\section{Voter turnout re-estimation}

Starting with the previous findings, I calculate the VEP and thus reestimate the turnout in the Romanian national elections for the period 1990-2012. Subtracting AVEP from VAP gives VEP, which is used next as the denominator for turnout computation. The official (BEC) turnout rate, the VAP INS turnout, and the VEP turnout are presented in Figure 5 (the corresponding figures are presented in Table 4 in the Appendix).

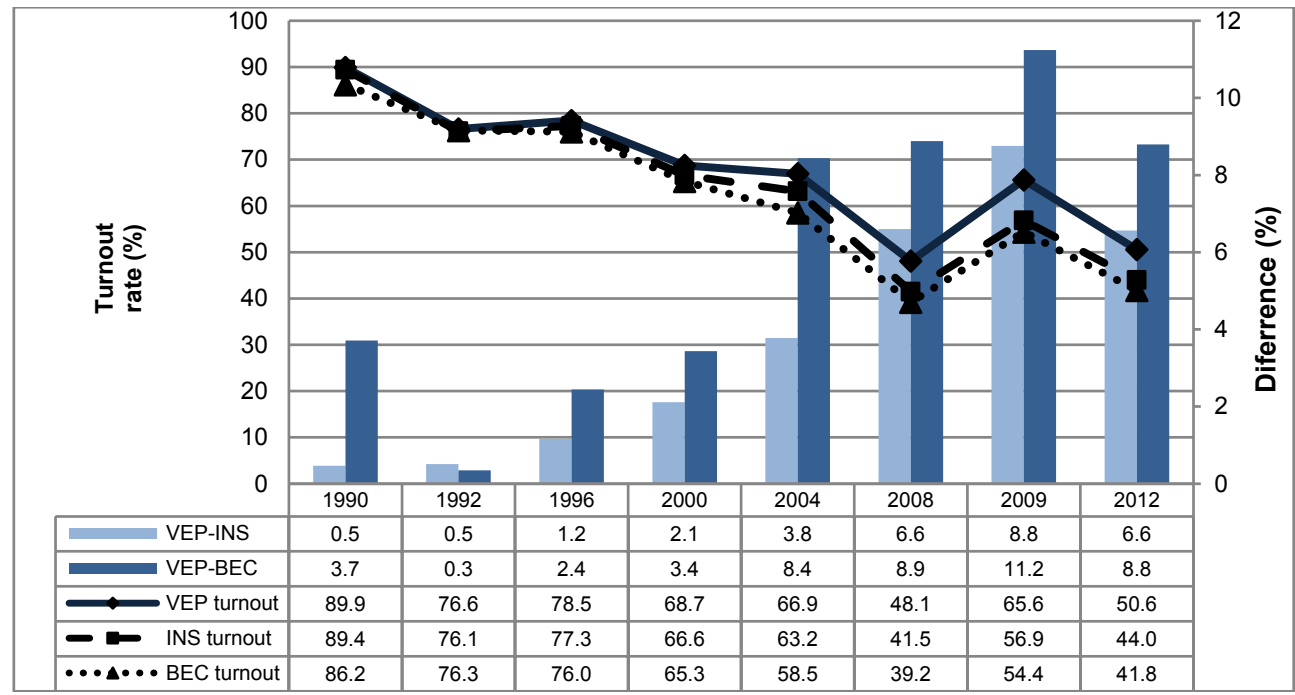

Figure 5. Official and re-estimated turnout rates, Romania 1990-2012

Data source: Personal computations based on data from BEC (www.bec2004.ro, http://www.becparlamentare2008.ro, www.bec2009p.ro, http://www.becparlamentare2012.ro), ROAEP (http://www.roaep.ro), and INS (Tempo Online, www.insse.ro)

Regardless of the estimation method considered, VT is decreasing. If, at the beginning of the period, VT was almost $90 \%$, at the end it decreases to $40-65 \%$, depending on the elections (presidential or parliamentary) and estimation method (BEC, INS, or VEP). However, the VT decrease varies greatly according to the type of data utilized. Considering the BEC and INS data, from 1990 to 2012, VT has decreased by approximately $45 \%$ for the parliamentary elections, and $32 \%$ for the presidential elections. The VEP turnout, although it still indicates a substantial decrease, shows that the decrease is significantly smaller: around $39 \%$ for parliamentary elections and $25 \%$ for presidential elections. Before the 2004 elections, the differences between the three estimations are rather small (1-4\%), but after that the differences increase quite a lot (7-11\%). Consequently, 
the VT decrease is not as big as the official data suggest. In addition, most of the decrease took place between 1990 and 2000. Even more, if one takes into account the fact that starting with 2008, the presidential and parliamentary elections are held separately, and one considers as a reference point the 2009 presidential elections, one can observe only a slight decrease in VT (3.1\%) during the last decade.

\section{Looking for external validation}

Increasingly inaccurate electoral registers and outward migration account for a large share of the observed decline in official turnout. To increase the validity of this finding, I have done two tests: a comparison between the Romanian official turnout, the re-estimated turnout, and the average turnout pattern from other post-communist countries and a test for spurious relationships between turnout and migration. Each one of these tests will offer additional support for the hypothesis.

The comparison between the Romanian turnout, the re-estimated turnout, and the post-communist turnout (Figure 6) reveals that beginning with the 2008 elections (migration increases at higher rates after 2004 and, especially, after 2007), the pattern of the VEP turnout in Romania is closer to the pattern in post-communist countries: the difference between the BEC turnout and turnout from post-communist countries is $-14.7 \%$, but the difference between the VEP turnout and turnout from post-communist countries is only $-5.0 \%$.
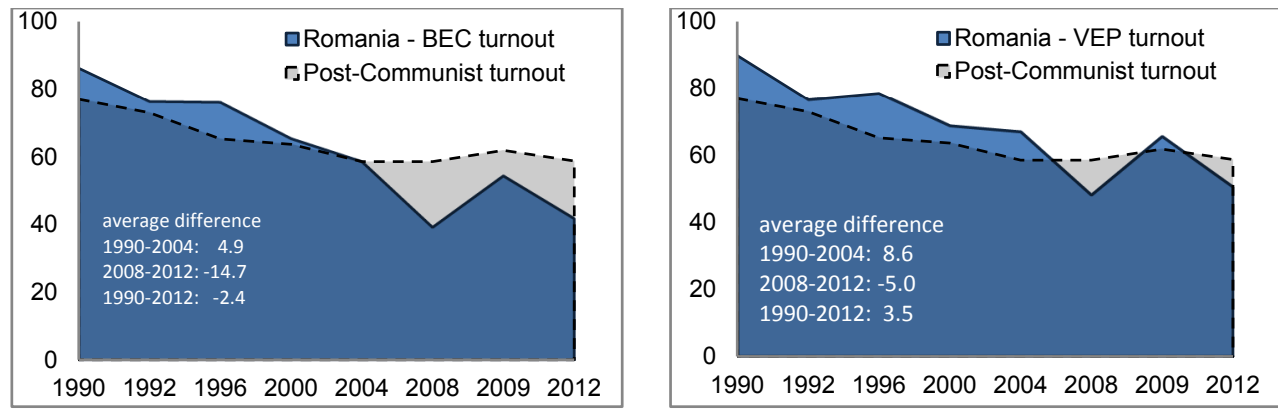

Figure 6. Official and re-estimated turnout rates in Romania vs. average postCommunist turnout

Data source: IDEA (www.idea.int/vt); average post-Communist turnout is computed as average from all Parliamentary elections held in the reference year +/- 1 year; for 2009 year Presidential elections are considered. 
The observed relationship between turnout and emigration could be a spurious one. In order to test for this, I have computed several time-series models with turnout rate (BEC and VAP) as a dependent variable, migration rate as an independent variable, and several control variables included one at time: GDP (per capita at PPP), party fractionalization, opposition fractionalization, inflation rate (log), unemployment rate, human development index, Gini index, overall globalization index, trust in government, and trust in Parliament (Table 1 in the Appendix). Due to the fact that most of these variables are non-stationary, dependent over time, and correlated among each other, I used ARIMA. With two exceptions, controlling for other variables does not change the relationship between turnout and migration. Even for these two control variables (opposition fractionalization and GDP), the sign of the relationship does not change, only its significance is reduced. So, the negative relationship between migration and turnout remains, even after controlling for these variables.

\section{Conclusions and implications}

In this paper I argue that the official data related to voter turnout in Romania (and possibly in other post-communist countries) are misleading. More precisely, the official VT in national elections ${ }^{19}$ is considerably underestimated. The main sources of the underestimation are the quality of the electoral lists, emigration and the voting ineligible population. If we take the actual VEP into account, turnout becomes significantly higher. Even more significantly, the difference between BEC turnout and VEP turnout shown in this study tends to increase over time. Therefore, even if there was a decrease in turnout between 1990 and 2012 in Romania, this is smaller than the official data count. Additionally, the largest part of the turnout decrease is concentrated between 1990 and 2000, and is less pronounced after that.

The analysis presented in this paper has at least two limitations. The first one concerns the fact that the methodology used to estimate the number of migrants is based upon partial and debatable data sometimes. Although multiple sources were used, the resulting values are most likely approximate only. However, large errors in the estimation of the number of migrants are transformed into relatively small errors in the estimation of the turnout. Therefore, the conclusions

19 The findings also apply in the case of the elections for the European Parliament. Applying the same methodology, the values of the turnout in the case of the euro-parliamentary elections in Romania are as follows:

\begin{tabular}{|c|c|c|c|c|c|}
\hline Elections & VEP & INS & BEC & VEP-INS & VEP-BEC \\
\hline 2007 & 35.8 & 30.9 & 29.5 & 4.9 & 6.3 \\
\hline 2009 & 33.2 & 28.8 & 27.7 & 4.4 & 5.5 \\
\hline
\end{tabular}


did not suffer any significant changes. The second limitation pertains to the fact that I investigated only the size of the VEP. A complete perspective would include an examination of the total number of votes cast. There are clues that the real number of votes cast is in fact smaller than the official one, especially in the case of the first elections (electoral fraud has decreased over time). If this is true, then in reality the turnout in the first elections was smaller, and therefore, the decrease in the turnout was smaller. Unfortunately though, estimating electoral fraud is difficult to carry out.

These findings have implications in many areas, such as scholarly and political debates (for example, people's support for democracy and democratic values, the legitimacy of government, and representation bias), methodological aspects (such as questioning the validity of empirical analyses that use official data as a measure of turnout and explaining some apparent turnout puzzles), and practical aspects (for example, the validation of elections where a threshold is present).

Most scholars and politicians consider the political participation of citizens to be one of the pillars of democracy. Without citizens' involvement (seen as a continuum from choosing representatives to participating in decisionmaking processes), a democracy cannot function (properly) (Czesnik, 2006; Lister and Pai, 2008). Among the different forms of political participation, voting is the most frequent and basic one (Blais, 2000; Verba et al., 1995). From a normative perspective that sustains a large amount of participation (Lijphart, 1997), a low turnout indicates a weak democracy. Even more, low turnout can be seen as a threat to democracy or as a luck of legitimacy of the elected government which, in return, could decrease the degree of acceptance of governmental decisions (Czesnik, 2006; Hadjar and Beck, 2010). Moreover, low turnout is associated with unequal political representation of different socio-demographic groups (Patterson, 2002; Teixeira, 1992; Wattenberg, 2002; White and McAllister, 2007) and, consequently, unequal political influence (Lijphart, 1997, 1998). In addition, low and falling turnout is considered a sign of disengagement and a decreasing commitment to democratic norms and duties (Norris, 1999; Teixeira, 1992). In the context of new democracies, these concerns are even more relevant, taking into question the unidirectionality of the democratization process (Huntington, 1991; Lijphart, 2000). Based on this paper's findings, one can argue that citizens from Romania, and from other post-socialist countries too, have not turned away from politics and democracy, at least not as much as the official statistics and current literature seem to imply.

A correct estimation of VT could be extremely important to the analyses that utilize this variable (mostly as a dependent one). Regardless of whether one analyze the dynamic of the turnout, compare turnout in different countries, or 
attempt to explain variations in turnout, the use of official data can be misleading and lead to incorrect results. The findings from this paper could also explain some apparent turnout puzzles: because educational attainment, party identification, mobilization by political parties, and ideological polarization are increasing, one should observe an increase in turnout too, but the opposite is seen.

In some (new) democracies, elections and referendums are considered valid only if a certain turnout threshold is surpassed. For example, in Romania, a referendum is validated only if $50 \%+120$ of the total registered population votes. ${ }^{21}$ For situations like these, the answer to the question of how much the turnout was becomes a decisive one for transposing people's preferences into laws and political decisions.

\section{Abbreviations:}

VT voter turnout

VAP voting age population

VEP voting eligible population

AVEP apparently voting eligible population

SER Romanian Electoral Studies

BOP Public Opinion Barometer

BEC Central Electoral Bureau

INS National Institute of Statistics

AEP Permanent Electoral Authority

CEC Central Electoral Commission

BNS National Bureau of Statistics

20 According to the Law regarding the organization of referendum, article 5, paragraph 2 (Monitorul Oficial, 24.02.2000).

${ }^{21}$ Recently, the law was changed and now the electoral threshold for referendum validation is $30 \%$ from total registered population. 


\section{REFERENCES}

*** (2006). Liberalizarea pieței muncii din România. Oportunităţi şi riscuri [Liberalization of Labour Market in Romania. Opportunities and Risks]. The Office for the Migration of the Workforce, București.

Bejan, A. (1991). Prezentarea şi analiza comparativă a rezultatelor alegerilor de la 20 mai 1990 [The presentation and analysis of May 20, 1990 elections results], In: Datculescu, P., Liepelt, K. (Eds.): Renaşterea unei democraţii. Alegerile din România de la 20 mai 1990 [The reborn of a democracy. Romanian elections of 20th May 1990]. București: Irsop.

Bell, J., (2001). The political economy of reform in post-communist Poland. Cheltenham: E. Elgar. Bernhagen, P., Marsh, M. (2007). Voting and Protesting: Explaining Citizen Participation in Old and New European Democracies. Democratization, 14: 44-72.

Bernstein, R., Chadha, A., Montjoy, R. (2001). Overreporting Voting: Why It Happens and Why It Matters. Public Opinion Quarterly, 65: 22-44.

Blais, A. (2000). To Vote or not to Vote: The Merits and Limits of Rational Choice Theory. Pittsburgh: University of Pittsburgh Press.

Blais, A., Gidengil, E., Nevitte, N. (2004). Where does turnout decline come from? European Journal of Political Research, 43: 221-236.

Burden, B.C. (2003). Internal and External Effects on the Accuracy of NES Turnout: Reply. Political Analysis, 11: 193-195.

Carey, F.H. (1995). Irregularities of rigging: The Romanian 1992 Parliamentary Elections. East European Quarterly, 29.

Clarke, H.D., Sanders, D., Stewart, M.C., Whiteley, P. (2004). Political Choice in Britain. Oxford: Oxford University Press.

Comşa, M. (2002). 0 analiză a ratei de răspuns în anchetele de opinie naţionale [An analysis of response rate in national opinion surveys]. Sociologie Românească, Vol.3-4/2002, pp. 1-32.

Comşa, M. (2004). Rată de participare, supra-raportare şi predicţii electorale [Turnout, overreporting and election forecasting]. Sociologie Românească, Vol.3/2004, pp. 50-73.

Comşa, M. (2010). Participarea la vot. De ce (nu) votează oamenii? [Voting. Why people (do not) vote?], In M. Comșa, A. Gheorghiţă, and D.C. Tufiş, (Eds.): Alegerile pentru Parlamentul European. România 2009. [European Parliamentary Elections. Romania 2009]. Iași: Polirom, pp. 55-108.

Czesnik, M. (2006). Voter turnout and democratic legitimacy in Central Eastern Europe. Pol. Sociol. Rev., 449-470.

Denver, D. (2003). Elections and voters in Britain. New York: Palgrave.

Duff, B., Hanmer, M.J., Park, W.-H., White, I.K. (2007). Good Excuses: Understanding Who Votes With An Improved Turnout Question. Public Opinion Quarterly, 71: 24-67.

Franklin, N.M., Lyons, P., Marsh, M. (2000). The tally of turnout: understanding crossnational turnout decline since 1945, Annual Meeting of the American Political Science Association, Washington D.C.

Gallego, A. (2009). Where Else Does Turnout Decline Come From? Education, Age, Generation and Period Effects in Three European Countries. Scand. Polit. Stud., 32: 23-44.

Hadjar, A., Beck, M. (2010). Who does not participate in elections in Europe and why is this? A multilevel analysis of social mechanisms behind non-voting. European Societies, 12: 521-542. 
Heath, O. (2007). Explaining turnout decline in Britain, 1964-2005: Party identification and the political context. Political Behavior, 29: 493-516.

Holbrook, A.L., Krosnick, J.A. (2010). Social Desirability Bias in Voter Turnout Reports: Tests Using the Item Count Technique. Public Opinion Quarterly, 74: 37-67.

Howard, M.M. (2003). Why post-communist citizens do not join voluntary organizations. In G. Bădescu and E.M. Uslaner (Eds.): Social capital and the transition to democracy. London: Routledge.

Huntington, S.P. (1991). The third wave: democratization in the late twentieth century. Norman: University of Oklahoma Press.

Hutcheson, D.S. (2004). Protest and disengagement in the Russian federal elections of 2003-04. Perspectives on European Politics and Society, 5: 305-330.

Inglehart, R., Catterberg, G. (2002). Trends in Political Action: The Developmental Trend and the Post-Honeymoon Decline. International Journal of Comparative Sociology, 43: 300-316.

Kostadinova, T. (2003). Voter turnout dynamics in post-Communist Europe. European Journal of Political Research, 42: 741-759.

Kostadinova, T. (2009). Abstain or Rebel: Corruption Perceptions and Voting in East European Elections. Politics \& Policy, 37: 691-714.

Kostadinova, T., Power, T.J. (2007). Does Democratization Depress Participation? Voter Turnout in the Latin American and Eastern European Transitional Democracies. Political Research Quarterly, 60: 363-377.

Kostelka, F. (2010). The Turnout Decline in the Post-Communist Members States of the EU: A Multicausal Explanation, The 3rd ECPR Graduate Conference, Dublin, 30th August - 1st September 2010.

Lijphart, A. (1997). Unequal Participation: Democracy's Unresolved Dilemma. American Political Science Review, 91: 1-14.

Lijphart, A. (1998). The problem of low and unequal voter turnout - and what we can do about it. Vienna: Institut für Höhere Studien.

Lijphart, A. (2000). Democracy in the twenty-first century: Can we be optimistic? Wassenaar: Netherlands Institute for Advanced Study in the Humanities and Social Sciences.

Lister, M., Pai, E. (2008). Citizenship in contemporary Europe. Edinburgh: Edinburgh University Press.

Mason, D.S. (2003). Fairness Matters: Equity and the Transition to Democracy. World Policy Journal, 20: 48-56.

Mattila, M. (2003). Why bother? Determinants of turnout in the European elections. Electoral Studies, 22: 449-468.

McDonald, P.M. (2003). On the Over-Report Bias of the National Election Survey. Political Analysis, 11: 180-186.

McDonald, P.M., Popkin, S.L. (2001). The myth of the vanishing voter. American Political Science Review, 95: 963-974.

Norris, P. (1999). Critical citizens: global support for democratic government. Oxford: Oxford University Press.

Norris, P. (2002). Democratic phoenix: reinventing political activism. Cambridge: Cambridge University Press.

Pacek, A.C. (1994). Macroeconomic conditions and electoral-politics in East-Central-Europe. Am. J. Polit. Sci., 38: 723-744. 
Pacek, A.C., Pop-Eleches, G., Tucker, J.A. (2009). Disenchanted or Discerning: Voter Turnout in Post-Communist Countries. Journal of Politics, 71: 473-491.

Patterson, T.E. (2002). The vanishing voter: public involvement in an age of uncertainty, 1st ed. Alfred A. Knopf: Distributed by Random House, New York.

Rose, R. (1995). Mobilizing Demobilized Voters in Post-Communist Societies. Party Politics, 1: 549-563.

Rotariu, T. (2012). Câteva comentarii prilejuite de o analiză sumară a informaţiilor statistice oficiale referitoare la alegerile prezidenţiale [Some comments on official statistics related to Presidential elections] In M. Comșa, A. Gheorghiță and C. Tufiș (Eds.): Alegerile prezidențiale din România, 2009 [The Presidential Elections in Romania, 2009]. Cluj-Napoca: Presa Universitară Clujeană.

Rotariu, T., Comșa, M. (2005). Alegerile generale 2004. O perspectivă sociologică [The 2004 National Elections. A sociological view]. Cluj-Napoca: Eikon.

Sandu, D. (2000). Migraţia circulatorie ca strategie de viaţă [Circular migration as a life strategy]. Sociologie Românească, Vol. 2/2000, pp. 5-29.

Sandu, D. (2006). Explorarea Europei prin migraţii pentru muncă: 1990-2006 [Exploring Europe through work migrations: 1990-2006], Locuirea temporară în străinătate. Migraţia economică a românilor: 1990-2006 [Temporary residence abroad. The economic migration of Romanians 1990-2006]. București: Fundaţia pentru o Societate Deschisă, pp. 13-39.

Sandu, D. (2010). Lumile sociale ale migraţiei româneşti în străinătate [Social Worlds of Romanian Migration Abroad]. Iași: Polirom.

Steiner, N.D. (2010). Economic globalization and voter turnout in established democracies. Electoral Studies, 29: 444-459.

Stockemer, D., LaMontagne, B., Scruggs, L. (2013). Bribes and ballots: The impact of corruption on voter turnout in democracies. International Political Science Review, 34: 74-90.

Sundström, A., Stockemer, D. (2013). Quality of government affect voter turnout in the European regions. QoG Working Paper Series.

Swaddle, K., Heath, A. (1989). Official and Reported Turnout in the British General Election of 1987. British Journal of Political Science, 19: 537-570.

Teixeira, R.A. (1992). The Disappearing American Voter. Washington DC: Brookings.

Tufis, C. (2012). Learning Democracy and Market Economy in Post-Communist Romania. Iași: Institutul European.

Tworzecki, H. (2003). Learning to choose: electoral politics in East-Central Europe. Stanford: Stanford University Press.

Verba, S., Schlozman, K.L., Brady, H.E. (1995). Voice and equality: civic voluntarism in American politics. Cambridge, Mass: Harvard University Press.

Wattenberg, P.M. (2002). Where Have All the Voters Gone? Cambridge, Mass: Harvard University Press.

White, S., McAllister, I. (2004). Dimensions of disengagement in post-communist Russia. Journal of Communist Studies and Transition Politics, 20: 81-97.

White, S., McAllister, I. (2007). Turnout and representation bias in post-communist Europe. Political Studies, 55: 586-606. 


\section{Appendix}

Table 1.

Turnout decline and emigration, Romania 1990-2012 (ARIMA models) ${ }^{22}$

\begin{tabular}{|c|c|c|}
\hline $\begin{array}{ll} & \text { Dependent variable } \\
\text { Independent variables } & \\
\end{array}$ & Turnout BEC & Turnout VAP \\
\hline Migrants share in total population & $\begin{array}{l}-2.54^{* *} \\
(0.43) \\
\end{array}$ & $\begin{array}{l}-2.48^{* *} \\
(0.45) \\
\end{array}$ \\
\hline Migrants share in total population & $\begin{array}{l}-2.23^{* *} \\
(0.42)\end{array}$ & $\begin{array}{l}-2.14^{* *} \\
(0.42)\end{array}$ \\
\hline Party fractionalization & $\begin{array}{c}-16.40^{* *} \\
(4.81) \\
\end{array}$ & $\begin{array}{c}-18.10^{* *} \\
(4.65) \\
\end{array}$ \\
\hline Migrants share in total population & $\begin{array}{l}-1.44 \\
(0.90)\end{array}$ & $\begin{array}{l}-1.39 \\
(0.94)\end{array}$ \\
\hline Opposition fractionalization & $\begin{array}{c}46.78+ \\
(27.03)\end{array}$ & $\begin{array}{c}46.67 \\
(29.13)\end{array}$ \\
\hline Migrants share in total population & $\begin{array}{l}-0.19 \\
(2.04)\end{array}$ & $\begin{array}{l}-1.13 \\
(2.14)\end{array}$ \\
\hline GDP per capita PPP & $\begin{array}{l}-0.00 \\
(0.00)\end{array}$ & $\begin{array}{l}-0.00 \\
(0.00)\end{array}$ \\
\hline Migrants share in total population & $\begin{array}{l}-1.63+ \\
(0.87)\end{array}$ & $\begin{array}{l}-1.87^{*} \\
(0.81)\end{array}$ \\
\hline Inflation rate $(\log )$ & $\begin{array}{c}9.29 \\
(6.90)\end{array}$ & $\begin{array}{c}6.24 \\
(6.87)\end{array}$ \\
\hline Migrants share in total population & $\begin{array}{l}-2.37^{* *} \\
(0.44)\end{array}$ & $\begin{array}{l}-2.32^{* *} \\
(0.45)\end{array}$ \\
\hline Unemployment rate & $\begin{array}{r}2.56^{*} \\
(1.07)\end{array}$ & $\begin{array}{l}-2.49^{*} \\
(1.17)\end{array}$ \\
\hline Migrants share in total population & $\begin{array}{l}-2.50^{* *} \\
(0.56)\end{array}$ & $\begin{array}{l}-2.58^{* *} \\
(0.57)\end{array}$ \\
\hline Human Development Index & $\begin{array}{l}-12.91 \\
(71.83) \\
\end{array}$ & $\begin{array}{c}33.96 \\
(66.91) \\
\end{array}$ \\
\hline Migrants share in total population & $\begin{array}{l}-2.40^{* *} \\
(0.42)\end{array}$ & $\begin{array}{l}-2.35^{* *} \\
(0.43)\end{array}$ \\
\hline Gini Index & $\begin{array}{l}-1.00 \\
(0.61)\end{array}$ & $\begin{array}{l}-0.96 \\
(0.65)\end{array}$ \\
\hline Migrants share in total population & $\begin{array}{l}-1.09^{*} \\
(0.55)\end{array}$ & $\begin{array}{l}-1.11^{*} \\
(0.56)\end{array}$ \\
\hline Overall globalization & $\begin{array}{l}-0.61^{* *} \\
(0.14)\end{array}$ & $\begin{array}{l}-0.58^{* *} \\
(0.18)\end{array}$ \\
\hline
\end{tabular}

22 Sources of control variables: party and opposition fractionalization (DPI 2010), GDP, inflation, and unemployment (International Monetary Fund, World Economic Outlook Database, April 2013), HDI and Gini index (WB), overall globalization (Steiner, 2010), trust in Romanian Parliament and Government (Tufis, 2012). 


\section{Independent variables}

\section{Dependent variable}

Migrants share in total population

Trust in Government

Migrants share in total population

Trust in Parliament
Turnout BEC

$-2.05^{* *}$

$(0.38)$

$0.29^{* *}$

$(0.06)$

$-2.19^{* *}$

$(0.34)$

$0.32^{* *}$

$(0.06)$
Turnout VAP

$-1.94^{* *}$

(0.37)

$0.33^{* *}$

$(0.06)$

$-2.10^{* *}$

$(0.32)$

$0.35^{* *}$

$(0.05)$

Standard errors in parentheses; + significant at $10 \%$; ${ }^{*}$ significant at $5 \%$; ${ }^{* *}$ significant at $1 \%$

Table 2.

Estimation of the number of Romanian emigrants

\begin{tabular}{|c|c|c|c|c|c|c|c|c|c|c|c|c|c|}
\hline 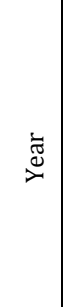 & 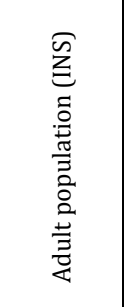 & 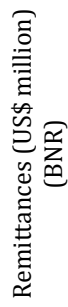 & 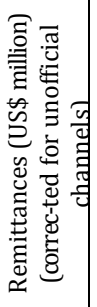 & 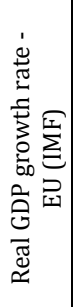 & 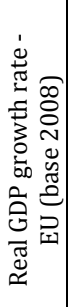 & 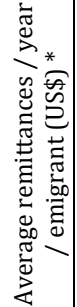 & 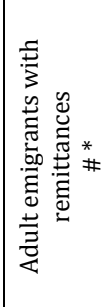 & 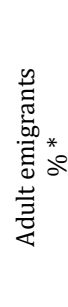 & 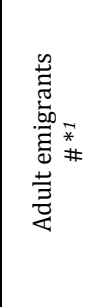 & 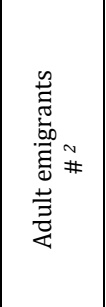 & 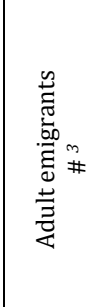 & 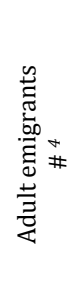 & 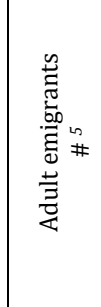 \\
\hline 1990 & & & & & & & & & & & 35,388 & & 35,388 \\
\hline 1991 & & & & & & & & & & & 63,600 & & 63,600 \\
\hline 1992 & & & & & & & & & & & 38,500 & & 38,500 \\
\hline 1993 & & & & & & & & & & & 39,055 & & 39,055 \\
\hline 1994 & $16,678,735$ & 11 & 176 & 2.9 & 64.9 & 3,980 & 44,219 & 0.750 & 58,958 & & 44,986 & & 51,972 \\
\hline 1995 & $16,812,270$ & 9 & 142 & 3.0 & 67.9 & 4,166 & 34,132 & 0.745 & 45,815 & & 55,119 & & 50,467 \\
\hline 1996 & $16,933,214$ & 18 & 281 & 2.0 & 69.9 & 4,290 & 65,461 & 0.740 & 88,461 & & 64,744 & & 76,602 \\
\hline 1997 & $17,029,060$ & 16 & 246 & 2.8 & 72.7 & 4,459 & 55,263 & 0.735 & 75,188 & & 112,403 & & 93,795 \\
\hline 1998 & $17,128,234$ & 49 & 745 & 3.0 & 75.7 & 4,642 & 160,458 & 0.730 & 219,806 & & 111,070 & & 165,438 \\
\hline 1999 & $17,247,528$ & 96 & 1,440 & 3.0 & 78.7 & 4,828 & 298,269 & 0.725 & 411,406 & & 127,190 & & 269,298 \\
\hline 2000 & $17,347,395$ & 96 & 1,421 & 4.0 & 82.7 & 5,071 & 280,179 & 0.720 & 389,138 & & 241,260 & & 315,199 \\
\hline 2001 & $17,421,518$ & 116 & 1,694 & 2.1 & 84.7 & 5,198 & 325,833 & 0.715 & 455,710 & & 315,614 & & 385,662 \\
\hline 2002 & $16,956,124$ & 143 & 2,059 & 1.4 & 86.1 & 5,283 & 389,755 & 0.710 & 548,951 & & 307,284 & & 428,117 \\
\hline 2003 & $17,018,741$ & 124 & 1,761 & 1.5 & 87.7 & 5,378 & 327,403 & 0.705 & 464,402 & & 569,013 & & 516,708 \\
\hline 2004 & $17,088,071$ & 132 & 1,848 & 2.7 & 90.4 & 5,543 & 333,405 & 0.700 & 476,292 & & 757,464 & & 616,878 \\
\hline 2005 & $17,181,515$ & 4,733 & 4,780 & 2.2 & 92.5 & 5,676 & 842,197 & 0.695 & $1,211,795$ & & 926,551 & & $1,069,173$ \\
\hline 2006 & $17,270,591$ & 6,718 & 6,785 & 3.4 & 96.0 & 5,886 & $1,152,733$ & 0.690 & $1,670,627$ & $1,838,547$ & 966,153 & & $1,491,776$ \\
\hline 2007 & $17,357,765$ & 8,542 & 8,627 & 3.1 & 99.1 & 6,075 & $1,420,093$ & 0.685 & $2,073,128$ & $2,181,078$ & $2,010,050$ & & $2,088,085$ \\
\hline
\end{tabular}




\begin{tabular}{|c|c|c|c|c|c|c|c|c|c|c|c|c|c|}
\hline 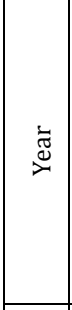 & 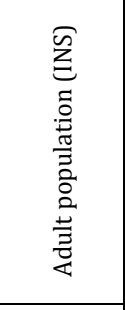 & 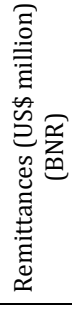 & 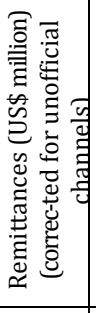 & 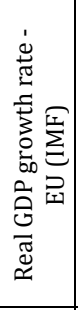 & 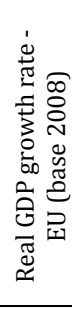 & 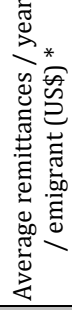 & 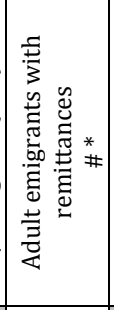 & 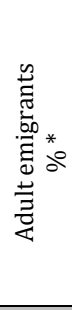 & 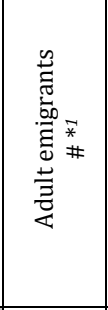 & 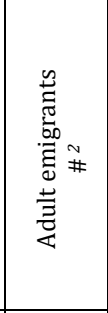 & 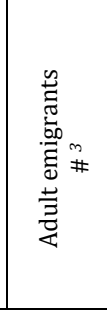 & 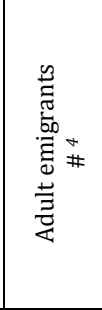 & 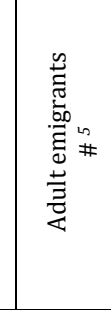 \\
\hline 008 & 449,417 & 9,381 & 9,475 & 0.9 & 100.0 & 6,133 & $1,544,806$ & 0.680 & $2,271,773$ & $2,224,733$ & $2,320,606$ & $1,813,306$ & $2,157,605$ \\
\hline 009 & $17,494,061$ & 4,952 & 5,002 & -4.1 & 95.9 & 3,067 & $1,630,930$ & 0.675 & $2,416,193$ & & $2,443,386$ & 1,764 & $2,208,132$ \\
\hline 010 & $17,495,174$ & 3,883 & 3,922 & -1.1 & 94.8 & 3,067 & $1,278,858$ & 0.670 & $1,908,743$ & & $2,425,384$ & & $2,167,063$ \\
\hline 011 & $17,488,264$ & 3,750 & 3,788 & 2.2 & 97.0 & 3,067 & $1,235,054$ & 0.665 & $1,857,225$ & & $2,376,158$ & & $2,116,691$ \\
\hline 2012 & $17,475,017$ & $\begin{array}{r}* \\
3,750 \\
\end{array}$ & 3,788 & 0.7 & 97.7 & 3,067 & $1,235,054$ & 0.660 & $1,871,294$ & & 434 & & $2,059,364$ \\
\hline
\end{tabular}

Values with grey background are estimations from surveys.

* Own estimation based on previous year.

1 Own estimation based on remittances.

${ }^{2}$ Estimations based on remittances (Sandu, 2010).

${ }^{3}$ Own estimations based on official data about the number of emigrants in Spain and Italy.

${ }^{4}$ Own estimations based on analysis of field operators sheets (sampling frame: BEC electoral lists).

${ }^{5}$ Mean of estimations (1-4).

Table 3.

The number of adults with psychological or mental disability and of those irrevocably convicted

\begin{tabular}{|c|c|c|}
\hline Year & $\begin{array}{l}\text { Adults with psychological } \\
\text { or mental disability }{ }^{1}\end{array}$ & $\begin{array}{l}\text { Adults irrevocably } \\
\text { convicted }^{2}\end{array}$ \\
\hline 1990 & $* 24,145$ & 26,010 \\
\hline 1992 & 48,289 & 21,961 \\
\hline 1993 & 104,244 & 21,838 \\
\hline 1994 & 139,987 & 21,869 \\
\hline 1995 & 135,733 & 24,556 \\
\hline 1996 & 154,713 & 23,097 \\
\hline 1997 & 141,229 & 26,714 \\
\hline 1998 & 145,135 & 37,566 \\
\hline 1999 & 144,240 & 38,110 \\
\hline 2000 & 141,886 & 36,447 \\
\hline 2001 & 146,639 & 37,406 \\
\hline 2002 & 146,732 & 37,448 \\
\hline 2003 & 143,351 & 36,104 \\
\hline
\end{tabular}


TURNOUT DECLINE IN ROMANIAN NATIONAL ELECTIONS: IS IT THAT BIG?

\begin{tabular}{|c|c|c|}
\hline Year & $\begin{array}{l}\text { Adults with psychological } \\
\text { or mental disability } 1\end{array}$ & $\begin{array}{l}\text { Adults irrevocably } \\
\text { convicted }^{2}\end{array}$ \\
\hline 2004 & 147,394 & 33,007 \\
\hline 2005 & 154,971 & 31,122 \\
\hline 2006 & 160,451 & 29,756 \\
\hline 2007 & 172,840 & 26,443 \\
\hline 2008 & 179,827 & 23,100 \\
\hline 2009 & 182,674 & 22,308 \\
\hline 2010 & 183,025 & 23,614 \\
\hline 2011 & 183,060 & 27,381 \\
\hline 2012 & 182,980 & $* * 27,381$ \\
\hline
\end{tabular}

${ }^{1}$ official data (ANPH, http://www.anph.ro/tematica.php?idt=13\&idss=41).

${ }^{2}$ official data (INS - TEMPO-Online, https://statistici.insse.ro/).

* estimation from a linear regression model (predictors: time and number of adults with disabilities)

** estimation based on previous year.

Table 4.

BEC, VAP and VEP turnout in Romanian national elections: 1990-2012

\begin{tabular}{|c|c|c|c|c|c|c|c|c|}
\hline Elections & $\begin{array}{c}\text { Votes } \\
\text { BEC }\end{array}$ & $\begin{array}{c}\text { VAP } \\
\text { BEC }\end{array}$ & $\begin{array}{c}\text { VAP } \\
\text { INS }\end{array}$ & AVEP & VEP & $\begin{array}{c}\text { Turn } \\
\text { out } \\
\text { BEC }\end{array}$ & $\begin{array}{c}\text { Turn } \\
\text { out } \\
\text { VAP }\end{array}$ & $\begin{array}{c}\text { Turn } \\
\text { out } \\
\text { VEP }\end{array}$ \\
\hline 1990 & $14,825,017$ & $17,200,720$ & $16,576,328$ & 80,173 & $16,531,543$ & 86.2 & 89.4 & 89.9 \\
\hline 1992 & $12,496,430$ & $16,380,663$ & $16,415,313$ & 98,010 & $16,355,803$ & 76.3 & 76.1 & 76.6 \\
\hline 1996 & $13,088,388$ & $17,218,654$ & $16,933,214$ & 254,275 & $16,755,541$ & 76.0 & 77.3 & 78.5 \\
\hline 2000 & $11,559,458$ & $17,699,727$ & $17,347,395$ & 492,608 & $17,169,985$ & 65.3 & 66.6 & 68.6 \\
\hline 2004 & $10,794,653$ & $18,449,344$ & $17,088,071$ & 796,727 & $16,908,222$ & 58.5 & 63.2 & 66.3 \\
\hline $2007-E P$ & $5,370,171$ & $18,224,597$ & $17,357,765$ & $2,287,585$ & $17,158,265$ & 29.5 & 30.9 & 35.6 \\
\hline 2008 & $7,238,871$ & $18,464,274$ & $17,449,417$ & $2,360,300$ & $17,246,721$ & 39.2 & 41.5 & 48.0 \\
\hline $2009-E P$ & $5,035,299$ & $18,197,316$ & $17,494,061$ & $2,413,115$ & $17,289,079$ & 27.7 & 28.8 & 33.4 \\
\hline $2009-P$ & $9,946,748$ & $18,293,277$ & $17,494,061$ & $2,414,421$ & $17,287,773$ & 54.4 & 56.9 & 66.0 \\
\hline 2012 & $7,694,180$ & $18,423,066$ & $17,488,264$ & $2,269,725$ & $17,277,903$ & 41.8 & 44.0 & 50.6 \\
\hline
\end{tabular}

Data source: Personal computations based on data from BEC (www.bec2004.ro, http://www.becparlamentare2008.ro, www.bec2009p.ro, http://www.becparlamentare2012.ro), ROAEP (http://www.roaep.ro), and INS (Tempo Online, www.insse.ro) 
